\title{
EFFORTS TO INCREASE INTEREST IN LEARNING MACHINE PRIME MOVER BOATS STUDENTS THROUGH LEARNING METHOD DEMONSTRATION IN CLASS X SMK NEGERI 1 SUTERA SUTERA DISTRICT OF SCHOOL YEAR 2015/2016
}

\author{
YULHENDRI
}

Volume 1 Nomor 1

JIPS ISSN: 2579-5449

\begin{abstract}
Basic education is education that underlies secondary education. Shaped elementary education elementary school (SD) and High School (SMP) and secondary education is a continuation of primary education, secondary education consists of general and vocational education. Shaped secondary education schools (SMA) and Vocational High School (SMK). Higher education is an education after secondary education includes educational programs diploma, bachelor's, master's, specialist, and doctoral organized by the college. " Does the application of machine learning methods of demonstration of interest in Prime Mover Boat class X in SMK 1 Silk can be improved ..?"

Implementation of Class Action Research conducted at SMK Negeri 1 Sutera. This research was motivated by the location of the school affordable.

This study is a Class Action Research with a total time of study 2 months from the month from September to October in Odd Semester Academic Year 2015 stars / 2016 . This study was planned to consist of two cycles, which aims to improve the activity and learning outcomes Prime Mover Engineering Ship class X SMK 1 Sutera in the second semester of the academic year 2015-2016.

Negeri 1 Sutera 's 27 people in the first semester of the academic year 2015 stars / 2016 .

Source Data in the study were students of class X SMK 1 Sutera .

As for how to capture data that is done in this study are as follows. Data on students' learning activities implemented actions taken when using the observation sheet. In the charging process observation sheets, all indicators of activity was observed contained therein. The observed circumstances are activities in the learning process. Data on study results taken from tests of learning outcomes at each end of the cycle consists of six items about.

Motor 2 TAK; Each piston-step process is required $2 \mathrm{x}, 1 \mathrm{x}$ crankshaft rotation while the piston between two steps, just one step affords effort. In size and the same rotation, the motor 2 TAK can produce more power than the motor 4 TAK. The piston and cylinder wall temperature is rather high.

Easy to administer and sound quiet bike. Construction is simple because it does not require the intake valve / exhaust. Filling / flushing and incomplete combustion. Rinse pump usage, add gear motor becomes expensive. Used if required a great power and a simple construction.
\end{abstract}

Subject of research is all class X SMK

Keywords: enginering prime mover boats 


\title{
UPAYA PENINGKATAN MINAT BELAJAR MESIN PENGGERAK UTAMA KAPAL SISWA MELALUI METODE PEMBELAJARAN DEMONTRASI PADA SISWA KELAS X SMK NEGERI 1 SUTERA KECAMATAN SUTERA TAHUN PELAJARAN 2015/2016
}

\begin{abstract}
ABSTRAK
Pendidikan dasar merupakan jenjang pendidikan yang melandasi jenjang pendidikan menengah. Pendidikan dasar berbentuk Sekolah Dasar (SD) dan Sekolah Menengah Pertama (SMP) dan pendidikan menengah merupakan lanjutan dari pendidikan dasar, terdiri atas pendidikan menengah umum dan pendidikan menengah kejuruan. Pendidikan menengah berbentuk Sekolah Menengah Atas (SMA) dan Sekolah Menengah Kejuruan (SMK). Pendidikan tinggi merupakan jenjang pendidikan setelah pendidikan menengah yang mencakup program pendidikan diploma, sarjana, magister, spesialis, dan doktor yang diselenggarakan oleh perguruan tinggi. "Apakah dengan penerapan metode demonstrasi minat belajar Mesin Penggerak Utama Kapal siswa kelas X pada SMK Negeri 1 Sutera dapat ditingkatkan..?"

Pelaksanaan Penelitian Tindakan Kelas dilaksanakan di SMK Negeri 1 Sutera. Penelitian ini dilatar belakangi oleh lokasi sekolah terjangkau.

Penelitian ini merupakan Penelitian Tindakan Kelas dengan total waktu penelitian 2 bulan yaitu dari bulan September - Oktober pada Semester Ganjil Tahun Ajaran 2015/2016. Penelitian ini direncanakan terdiri atas 2 siklus, yang bertujuan untuk meningkatkan aktivitas dan hasil belajar Mesin Penggerak Utama Kapal siswa kelas X SMK Negeri 1 Sutera pada semester genap tahun ajaran 2015-2016.

siswa kelas $\mathrm{X}$ SMK Negeri 1 Sutera yang berjumlah 27 orang pada semester ganjil tahun ajaran 2015/2016.

Sumber data dalam penelitian adalah siswa kelas X SMK Negeri 1 Sutera.

Adapun cara pengambilan data yang dilakukan dalam penelitian ini adalah sebagai berikut. Data tentang aktivitas belajar siswa diambil pada saat dilaksanakan tindakan dengan menggunakan lembar observasi. Pada proses pengisian lembar observasi, semua indikator dari aktivitas yang diamati tercantum didalamnya. Keadaan yang diobservasi adalah kegiatan siswa dalam proses pembelajaran. Data mengenai hasil belajar yang diambil dari tes hasil belajar pada setiap akhir siklus yang terdiri atas 6 item soal.

Motor 2 TAK ; Tiap proses diperlukan $2 \mathrm{x}$ langkah torak, $1 \mathrm{x}$ putaran poros engkol sedangkan diantara 2 langkah torak, hanya 1 langkah saja yang memberikan usaha. Pada ukuran dan putaran yang sama, motor 2 TAK dapat menghasilkan tenaga lebih besar dari pada motor 4 TAK. Suhu torak dan dinding silinder agak tinggi.

Mudah dijalankan dan tenang suara motornya. Konstruksi sederhana karena tidak memerlukan katup masuk /buang. Pengisian / pembilasan dan pembakaran kurang sempurna. Pemakaian pompa bilas, menambah perlengkapan motor menjadi mahal. Dipakai jika diperlukan tenaga yang besar dan konstruksi sederhana.
\end{abstract}

Subjek penelitian ini adalah seluruh

\section{Kata Kunci : mesin penggerak utama kapal}

\section{PENDAHULUAN}

Latar belakang Salah satu tujuan pendidikan nasional bangsa Indonesia di dalam pembukaan Undang-undang Dasar Negara Republik Indonesia tahun 1945 adalah untuk mencerdaskan kehidupan bangsa. Pencapaian tujuan nasional untuk mencerdaskan kehidupan bangsa dilakukan melalui pendidikan. Sistem Pendidikan Nasional di Indonesia mulai dari jenjang pendidikan dasar sampai jenjang pendidikan tinggi.

Pendidikan dasar merupakan jenjang pendidikan yang melandasi jenjang pendidikan 


\section{Jurnal Ilmiah Pendidikan Scholastic}

menengah. Pendidikan dasar berbentuk Sekolah Dasar (SD) dan Sekolah Menengah Pertama (SMP) dan pendidikan menengah merupakan lanjutan dari pendidikan dasar, terdiri atas pendidikan menengah umum dan pendidikan menengah kejuruan. Pendidikan menengah berbentuk Sekolah Menengah Atas (SMA) dan Sekolah Menengah Kejuruan (SMK). Pendidikan tinggi merupakan jenjang pendidikan setelah pendidikan menengah yang mencakup program pendidikan diploma, sarjana, magister, spesialis, dan doktor yang diselenggarakan oleh perguruan tinggi.

Jenjang pendidikn menengah terdapat dua alternatif pilihan yaitu bias SMA atau SMK. Perbedaan keduanya adalah bahwa untuk SMA merupakan pendidikan menengah yang masih bersifat umum dan belum menjurus ke keahlian tertentu, sedangkan untuk SMK merupakan pendidikan yang bersifat khusus dan sudah menjurus pada keahlian tertentu berdasarkan program keahliannya. Program keahlian yang ditawarkan di SMK antara lain perikanan, permesinan, otomotif, elektronika, bangunan, akuntansi, manajemen dan lain-lain.

Menurut Undang-Undang No. 2 Tahun 1989 tentang Sistem Pendidikan Nasional : "Pendidikan kejuruan merupakan pendidikan yang mempersiapkan peserta didik untuk dapat bekerja di bidang tertentu". Arti pendidikan kejuruan ini dijabarkan lebih spesifik dalam perturan pemerintah nomor 29 tahun 1990 tentang pendidikan menengah, yaitu: Pendidikan menengah kejuruan adalah pendidikan pada jenjang menengah yang mengutamakan pengembangan kemampuan siswa untuk melaksanakan jenis pekerjaan tertentu (Wardiman, 1998:31).

Inti dari mata pelajaran yang diberikan di SMK adalah komponen yang bersifat produktif yaitu mata pelajaran yang memberikan pelajaran keterampilan produktif sesuai dengan jurusannya atau sesuai dengan apa yang dibutuhkan di tempat kerja. Pelajaran yang diberikan mulai dari materi dasar sampai materi pokoknya. Materi dasar yang diberikan harus sesuai dengan jurusannya artinya bahwa materi tersebut nantinya dapat dipakai untuk pelajaran-pelajaran lain yang diberikan selanjutnya, dengan kata lain materi dasar diberikan sebelum materi pokoknya.

Menurut Wardiman (1998:57), bahwa kebiasaan salah di SMK pada saat kegiatan pembelajaran antara lain guru mengajar dengan cara menulis di papan tulis. Proses pembelajaran tidak menerapkan sistem belajar tuntas, proses pengajaran yang ditampilkan tidak berwawasan ekonomi, tidak berwawasan nilai tambah, guru tidak mendorong siswa belajar dari buku (belajar hanya pada apa yang dijelaskan lisan dan ditulis guru), dan tidak membetuk etos kerja serta guru tidak membuat lembar kerja atau rencana pelaksanaan pembelajaran (RPP).

Hasil observasi lapangan (kelas), pada kegiatan proses belajar mengajar (PBM) menunjukkan aktivitas siswa dalam proses belajar-mengajar rendah dan bersifat pasif yaitu cenderung hanya sebagai penerima saja. Siswa kelihatan tidak bersemangat banyak yang mengantuk dan kurang memperhatikan materi yang disampaikan guru. Siswa kurang berminat selama mengikuti proses pembelajaran, siswa kurang berani mengemukakan pendapatnya bila diberi pertanyaan oleh guru. Proses kegiatan belajar mengajar didominasi dengan kegiatan mencatat di papan tulis dan ceramah.

Melihat kondisi siswa ini menunjukkan bahwa minat belajar siswa masih rendah. Minat belajar siswa ditunjukkan dengan adanya perasaan senang, perhatian dan adanya aktivitas yang merupakan akibat dari rasa senang dan perhatian. Banyak hal yang menyebabkan kondisi di atas terjadi, misalnya berasal dari diri pribadi siswa sendiri dan dari luar pribadi siswa sendiri yang kemudian dapat mempengaruhi minat belajar siswa ketika kegiatan belajar mengajar sedang berlangsung. Beberapa contoh yang berasal dari dalam pribadi siswa misalnya: siswa mengalami masalah pribadi yang bisa menurunkan minat belajarnya, atau yang berasal dari luar pribadi siswa misalnya: metode pembelajaran hanya ceramah dan mencatat di papan tulis atau bahkan bisa berasal dari guru sendiri sebagai pemberi materi pelajaran.

Minat belajar siswa penting untuk ditingkatkan karena mempermudah proses belajar serta untuk mencapai prestasi yang lebih tinggi dari sebelumnya. Minat merupakan alat motivasi yang pokok karena proses belajar akan berjalan lancar kalau disertai minat. Mengenai minat ini antara lain dapat dibangkitkan dengan cara-cara sebagai berikut: menggunakan berbagai macam metode mengajar, membangkitkan adanya suatu kebutuhan, member kesempatan untuk mendapatkan hasil yang lebih baik.

Menurut Soekidjo (2003:59), dalam proses penyampaian materi pendidikan kepada sasaran pendidikan, di samping kurikulum maka metode dan alat pendidikan turut memegang peranan penting. Sebab bagaimanapun pandainya seorang pendidik dalam usahanya mengubah 


\section{Jurnal Ilmiah Pendidikan Scholastic}

tingkah laku, tidak terlepas dari metode dan alat bantu pendidikan yang digunakan. Metode dan alat bantu pendidikan yang baik akan mempermudah proses belajar dan mengajar.

Dalam pelaksanaan kegiatan belajar banyak menggunakan jenis metode yang bisa digunakan oleh pendidik dalam menerangkan materi ajar kepada siswa. Masing-masing jenis metode memiliki kemampuan sendiri-sendiri dalam mengungkapkan dan menggambarkan bahan ajar yang disampaikan guru. Begitu pula kualitas efeknya terhadap pemahaman siswa yang ditimbulkan.

Penyebab kurangnya minat dan motivasi belajar siswa disebabkan karena cara mengajar guru tidak menarik dan monoton, kurangnya alat dan bahan, tidak adanya media dalam proses belajar mengajar.

Untuk itu peneliti tergugah untu melakukan penelitian tindakan kelas denga menggunakan metode demonstrasi untu menimbulkan minat belajar siswa. Menurt Muhibbin 1995:201) Syah metode demontras adalah metode mengajar dengan car memperagakan barang, kejadian, aturan dan urutan melakukan kegiatan, baik secara langsung maupun melalui penggunaan media pengajaran yang relevan dengan pokok bahasan atau materi yang sedang di sajikan.

Dengan dilakukannya metode demontrasi dalam proses belajar mengajar perhatian siswa dapat lebih dipusatkan, proses belajar siswa lebih terarah pada materi yang sedang dipelajari, pengalaman dan kesan sebagai hasil pembelajaran lebih melekat dalam diri siswa, memudahkan berbagai jenis penjelasan dan

\section{METODE PENELITIAN}

Pelaksanaan Penelitian Tindakan Kelas dilaksanakan di SMK Negeri 1 Sutera. Penelitian ini dilatar belakangi oleh lokasi sekolah terjangkau. Penelitian ini merupakan Penelitian Tindakan Kelas dengan total waktu penelitian 2 bulan yaitu dari bulan September - Oktober pada Semester Ganjil Tahun Ajaran 2015/2016.

Penelitian ini direncanakan terdiri atas 2 siklus, yang bertujuan untuk meningkatkan aktivitas dan hasil belajar Mesin Penggerak Utama Kapal siswa kelas X SMK Negeri 1 Sutera pada semester genap tahun ajaran 20152016. Sumber data dalam penelitian adalah siswa kelas X SMK Negeri 1 Sutera. Data kuantitatif dari hasil observasi aktivitas belajar membantu anak didik memahami dengan jelas kejadian, aturan dan urutan melakukan suatu kegiatan.

Masalah PTK ini dapat di identifikasi sebagai berikut: a) Pembelajaran mesin penggerak utama kapal di kelas masih monoton. b) Belum ditemukan strategi pembelajaran yang tepat. c) Belum ada kolaborasi antara guru dan siswa. d) Metode yang digunakan bersifat konvensional. e) Rendahnya kualitas hasil pembelajaran mesin penggerak utama kapal. f) Rendahnya minat belajar siswa pada mata pelajaran mesin penggerak utama kapal

Rumusan Masalah, "Apakah dengan penerapan metode demonstrasi minat belajar Mesin Penggerak Utama Kapal siswa kelas X pada SMK Negeri 1 Sutera dapat ditingkatkan..?"

Metode pemecahan masalah yang akan digunakan dalam penelitian ini, yaitu pembelajaran metode demontrasi, dengan metode pembelajaran ini diharapkan dapat meningkatkan minat belajar melalui pelajaran mesin penggerak utama kapal.

Berdasarkan uraian kajian teoritis diatas, maka rumusan hipotesis tindakan pada penelitian ini adalah Penerapan Metode Demonstrasi dapat meningkatkan minat belajar siswa kelas X pada mata pelajaran Mesin Penggerak Utama Kapal SMK Negeri 1 Sutera.

Tujuan penelitian adalah untuk mengetahui apakah metode demonstrasi dapat meningkatkan hasil belajar Mesin Penggerak Utama Kapal pada siswa kelas X pada SMK Negeri 1 Sutera.

dan nilai hasil belajar siswa.

Adapun cara pengambilan data, data tentang aktivitas belajar siswa diambil pada saat dilaksanakan tindakan dengan menggunakan lembar observasi. Pada proses pengisian lembar observasi, semua indikator dari aktivitas yang diamati tercantum didalamnya. Keadaan yang diobservasi adalah kegiatan siswa dalam proses pembelajaran. Data mengenai hasil belajar yang diambil dari tes hasil belajar pada setiap akhir siklus yang terdiri atas 6 item soal.

Dalam PTK ini yang akan dilihat indikator kinerjanya selain siswa adalah guru, karena merupakan fasilitator yang sangat berpengaruh terhadap kinerja siswa. 


\section{Jurnal Ilmiah Pendidikan Scholastic}

Siswa a) Tes : rata-rata nilai ulangan harian. b) Observasi : keaktifan siswa dalam proses belajar mengajar. Guru, a) Dokumentasi : kehadiran siswa b) Observasi : hasil observasi

Analisis Data dalam Penelitian tindakan kelas terdiri dari 2 jenis yaitu sebagai berikut :a Menggunakan analisis statistik deskriptif yang meliputi rata - rata, standar deviasi, modus, median dan tabel distribusi frekuensi. b Kriteria hasil belajar dapat dihitung dengan menggunakan rumus

Keterangan: $\mathrm{X}=$ Rerata

$$
\begin{aligned}
\sum \mathrm{x} & =\text { Jumlah Nilai Seluruh Siswa } \\
\mathrm{N} & =\text { Banyaknya Siswa }
\end{aligned}
$$

Menurut Depdiknas 2003;14 rumus yang digunakan dalam menghitung hasil belajar afektif dan psikomotorik adalah

Nilai $=$ X $100 \%$

a. $\quad$ Ketuntasan belajar siswa menurut (Ali, 1984;184) dihitung dengan menggunakan rumus: $\%$

Keterangan: $\%=$ Presentase

$$
\begin{aligned}
\mathrm{n} & =\text { Jumlah skor yang diperoleh } \\
\mathrm{N} & =\text { Jumlah Skor Maksimal }
\end{aligned}
$$

Analisis Data Kualitatif a) Data aktivitas siswa berdasarkan hasil observasi dan data respons siswa berdasarkan pengisian angket. b) Diuraikan perubahan sikap dan aktivitas siswa selama proses pelaksanaan tindakan secara deskriptif. c) Diuraikan respons siswa tentang pelaksanaan tindakan, yakni kemudahan dan kesulitan yang mereka alami serta saran untuk perbaikan tindakan berikutnya

Menurut Moleong (2001:165), proses analisis data dimulai dengan menelaah seluruh data yang terjadi dari berbagai sumber yaitu hasil pengamatan, wawancara, catatan lapangan dengan indikator keberhasilan yang ditetapkan pada tahap refleksi dari siklus penelitian.

Data yang terkumpul dari hasil observasi aktivitas siswa dan aktivitas guru dianalisis secara kualitatif melalui analisis evaluasi dan refleksi dengan melalui tahapan yaitu reduksi data, penyajian data dan penarikan kesimpulan.

Sesuai dengan pendapat Miles \& Huberman (1992:160)

bahwa data yang dianalisis secara kualitatif, meliputi 3 alur yaitu reduksi data, penyajian data, dan penarikan kesimpulan. Data yang diperoleh melalui perangkat pengumpulan data akan dianalisis dan selanjutnya direduksi secara sistematis. Data tereduksi ini akan disajikan secara terorganisir untuk dilakukan penarikan kesimpulan.

Data yang terkumpul dari hasil angket dianalisis secara kuantitatif untuk melihat persentase tiap item dari tanggapan siswa. Data mengenai prestasi belajar siswa dianalisis secara deskriptif kuantitatif untuk melihat rata - rata hasil belajar dan tingkat pemahaman siswa.

Tingkat pemahaman diukur berdasarkan kriteria seperti table dibawah ini :

Tabel 2. Kriteria Tingkat Pemahaman Siswa

\begin{tabular}{|c|c|c|}
\hline No & Tingkat Penguasaan (\%) & Kategori \\
\hline 1. & $90-100$ & Sangat Baik \\
2. & $80-89$ & Tinggi \\
3. & $65-79$ & Sedang \\
4. & $55-64$ & Rendah \\
5. & $0-54$ & Sangat Rendah \\
\hline
\end{tabular}

3. Indikator Keberhasilan

Indikator dalam penelitian tindakan ini meliputi indikator kinerja seperti rata - rata, ketuntasan atau KKM dan aktivitas belajar, kemandirian. Dari segi kinerja ditandai dalam proses pembelajaran baik dalam kerja kelompok maupun diskusi kelompok sesuai dengan rencana dan memenuhi tahap-tahap pembelajaran metode demonstrasi dan hasil evaluasi pemahaman siswa jika semua siswa kelas X SMK Negeri 1 Sutera memperoleh nilai 7,0. maka siklus berikutnya tidak dilanjutkan lagi karena indikator keberhasilan telah tercapai.

Sesuai dengan kriteria standar yang diungkapkan Nurkancana (1986: 39) sebagai berikut: Tingkat penguasaan $90 \%-100 \%$ dikategorikan sangat tinggi, $80 \%-89 \%$ dikategorikan tinggi, 65\% - 79\% dikategorikan 


\section{Jurnal Ilmiah Pendidikan Scholastic}

sedang, 55\% - 64\% dikategorikan rendah, dan $0 \%$ - 54\% dikategorikan sangat rendah.

\section{H. Instrumen Penelitian}

Instrumen yang digunakan dalam penelitian ini adalah :

1. Lembar observasi aktivitas siswa selama proses pembelajaran melalui penerapan pembelajaran metode demontrasi.

2. Tes hasil belajar yang terdiri dari 6 item soal yang diberikan pada setiap akhir siklus.

I. Prosedur Penelitian

Penelitian tindakan kelas (Classroom Action Research) diawali dengan refleksi awal yang dilakukan peneliti yang berkolaborasi dengan partisipan mencari informasi lain untuk mengenali dan mengetahui kondisi awal atau mencari masalah yang ada pada tempat yang akan dijadikan sebagai subjek penelitian. Secara umum penelitian tindakan kelas memiliki desain dengan 4 langkah utama, yaitu perencanaan tindakan, pelaksanaan tindakan, pengamatan dan evaluasi, serta refleksi.

Penelitian ini direncanakan terdiri atas 2 siklus, dimana setiap siklus terdiri atas 3 kali tatap muka. Setiap tatap muka berlangsung selama 3 jam pelajaran ( 3 X 45 menit). Pada akhir setiap siklus dilakukan revisi tindakan, dan evaluasi hasil belajar. Pelaksanaan tindakan setiap siklus mengikuti langkah-langkah skenario sebagai berikut:

Siklus I :
a. Merancang tindakan siklus I
b. Melaksanakan tindakan
c. Memantau tindakan yang dilaksanakan
d. Mengevaluasi hasil observasi
e. Mengadakan refleksi
Siklus II :

a. Merancang tindakan siklus II berdasarkan refleksi siklus I

b. Melaksanakan tindakan perbaikan

c. Memantau tindakan yang dilaksanakan

d. Mengevaluasi hasil observasi II

e. Mengadakan refleksi II

Selanjutnya diuraikan gambaran kegiatan

yang dilakukan masing-masing siklus sebagai berikut:

\section{Siklus Pertama}

Kegiatan yang dilakukan pada siklus pertama adalah sebagai berikut :

a. Diagnosis Masalah

$$
\text { Diagnosis }
$$

masalah

yaitu

mengidentifikasi masalah sebelum merencanakan dan melakukan tindakan penelitian sehingga menghasilkan gagasan untuk melakukan perbaikan-perbaikan metode mengajar guru di depan kelas. Pada tahap ini peneliti mengamati masalah-masalah aktual yang terjadi kemudian dijadikan sebagai bahan dasar rencana dan tindakan penelitian. Berdasarkan hasil observasi maka masalahnya adalah kurangnya minat belajar siswa dalam pembelajaran dan rendahnya hasil belajar siswa.

Hasil observasi ini kemudian dihubungkan dengan hasil-hasil kajian teori yang relevan, sehingga menghasilkan sesuatu program pengembangan tindakan yang dipandang akurat dan sesuai situasi lokasi dimana program tindakan dikembangkan.

b. Perencanaan

1) $\square$ Melakukan observasi awal dan wawancara dengan guru mitra tentang pelaksanaan penelitian

2) $\square$ Melakukan pertemuan dengan kepala sekolah tentang izin pelaksanaan penelitian di sekolah

3) $\square$ Pertemuan dengan guru mitra untuk menelaah kurikulum dan persiapan materi pembelajaran. Dalam hal ini disepakati untuk mengembangkan pokok bahasan tentang prinsip kerja motor bensin dan motor diesel.

4) $\square$ Penyusunan instrument penelitian meliputi. Penyusunan rencana pembelajaran, pengembangan materi ajar, penyusunan instrument penelitian meliputi instrument observasi, instrument angket, instrument hasil tes belajar

5) $\square$ Peneliti bersama guru mitra mendiskusikan tentang langkah - langkah pembelajaran yang akan dilakukan

6) $\square$ Kesepakatan dengan guru tentang pelaksanaan tindakan dimana guru mitra sebagai pengajar dan peneliti sebagai observer dalam kegiatan pembelajaran

Pelaksanaan tindakan diawali dengan memperkenalkan strategi pembelajaran yang akan dilaksanakan dengan menjelaskan langkah - langkah penyusunan metode demonstrasi sebagai berikut : 1) Mulailah demonstrasi dengan kegiatan-kegiatan yang merangsang siswa untuk berpikir. 2) Ciptakan suasana yang menyejukkan dengan menghindari suasana yang menegangkan. 3) Yakinkan bahwa semua siswa mengikuti jalannya demonstrasi dengan memperhatikan reaksi seluruh siswa. 4) Berikan kesempatan kepada siswa untuk secara aktif memikirkan lebih lanjut sesuai dengan apa yang dilihat dari proses demonstrasi itu.

Setelah siswa diajar tentang langkah - 


\section{Jurnal Ilmiah Pendidikan Scholastic}

langkah metode demonstrasi maka pertemuan berikutnya dilaksanakan sesuai dengan Rencana Pembelajaran yang

telah

disiapkan sebagai berikut :

1. Guru memberikan apersepsi dan motivasi kepada peserta didik

2. Guru menjelaskan materi tentang prinsip kerja motor bensin dan motor diesel.

3. Guru menjelaskan secara singkat bagaimana proses pembelajaran dengan metode demonstrasi.

4. Terjadi proses Tanya jawab antara guru dan peserta didik

5. Guru membagikan LKS kepada peserta didik

6. Siswa dibagi dalam 5 kelompok, setiap kelompok terdiri dari 5 - 6 siswa.

7. Siswa mempersiapkan alat dan bahan yang digunakan dalam praktek mesin bensin dan motor diesel.

8. Guru memberikan post tes pada siswa.

9.

\section{PERTEMUAN PERTAMA}

\section{Kegiatan Awal}

a. Absensi

b. Memotivasi dan Apersepsi

- Guru menyampaikan pertanyaanpertanyaan tentang prinsip kerja motor bensin dan motor diesel.

- Siswa menyimak tujuan pembelajaran yang diberikan oleh guru untuk kegiatan pembelajaran hari ini.

2. Kegiatan inti

- Guru mengajukan pertanyaan kepada siswa tentang prinsip kerja motor bensin dan motor diesel

- Siswa mendengarkan materi yang akan dijelaskan oleh guru.

3. Kegiatan Akhir

- Siswa bersama guru membuat kesimpulan materi hari ini.

- Guru memberikan tugas kepada peserta didik

- Guru menyampaikan materi untuk pertemuan berikutnya.

\section{PERTEMUAN KEDUA}

1. Kegiatan Awal

a. Absensi

b. Memotivasi dan Apersepsi

- Guru menyampaikan prinsip kerja motor bensin dan motor diesel.

- Siswa menyimak tujuan pembelajaran yang diberikan oleh guru untuk kegiatan pembelajaran hari ini.

2. Kegiatan inti
- Guru mengajukan pertanyaan kepada siswa tentang prinsip kerja motor bensin dan motor diesel

- Guru menjelaskan prinsip-prinsip kerja motor bensin dan motor diesel

3. Kegiatan Akhir

- $\square$ Siswa bersama guru membuat kesimpulan materi hari ini.

○ $\square$ Guru memberikan tugas kepada peserta didik

○ $\square$ Guru menyampaikan materi untuk pertemuan berikutnya.

d. Observasi

Kegiatan yang dilakukan pada tahap ini adalah sebagai berikut

- $\square$ Melakukan observasi pada tahapan tertentu dan mengisi daftar cek observasi

○ $\square$ Mencatat kejadian - kejadian penting di kelas setiap kali proses pembelajaran

- $\quad \square$ Melaksanakan tes pada akhir siklus

e. Refleksi

Kegiatan yang dilakukan pada tahap ini adalah sebagai berikut

○ $\square$ Evaluasi pelaksanaan pembelajaran dikelas oleh tim peneliti

○ $\square$ Diskusi tim peneliti tentang hasil yang dicapai, mengidentifikasi masalah yang belum teratasi dan menetapkan terapinya

○ $\square$ Meminta tanggapan siswa tentang pelaksanaan pembelajaran

Hasil refleksi siklus pertama dijadikan landasan untuk perbaikan tindakan pada siklus ke dua

2. Siklus Kedua

Pada siklus kedua dilakukan pembelajaran dengan langkah - langkah sama dengan siklus pertama tapi didahului dengan perencanaan ulang untuk memperbaiki kekurangan dan kelemahan pada pembelajaran siklus pertama.

a. Perencanaan

Kegiatan yang dilaksanakan dalam perencanaan adalah :

1. Menyusun Rencana Pelaksanaan Pembelajaran (RPP) materi pinsip kerja motor bensin dan motor diesel sesuai dengan silabus SMK.

2. Menyusun soal post tes materi Mesin Penggerak Utama Kapal yang digunakan untuk mengetahui hasil belajar kognitif dan kemampuan berpikir siswa.

3. Menyusun lembar observasi berupa lembar afektif dan psikomotorik yang akan digunakan untuk menilai kegiatan siswa dalam proses pembelajaran.

b. Pelaksanaan Tindakan 


\section{Jurnal Ilmiah Pendidikan Scholastic}

Tindakan yang dilakukan pada tahap ini adalah guru melaksanakan kegiatan pembelajaran sesuai skenario yang telah direncanakan. Pada siklus ini berjalan selama 3 jam pelajaran dengan kegiatan sebagai berikut :

1. Guru membuka pelajaran dengan memberikan beberapa pertanyaan yang berkaitan dengan materi prinsip-prinsip kerja motor bensin dan motor diesel.

2. Guru menjelaskan secara singkat bagaimana proses pembelajaran yang akan dilaksanakan.

3. Siswa mempersiapkan bahan pelajaran yang digunakan untuk materi prinsip-prinsip kerja motor bensin dan motor diesel.

4. Guru membimbing dan mengarahkan siswa .

5. Siswa menyebutkan bagian-bagian jenis mesin dengan penggerak motor bensin dan motor diesel sesuai petunjuk.

6. Guru dan siswa melakukan tanya jawab untuk menyimpulkan hasil pembelajaran, guru memberikan penegasan tentang kesimpulan Materi dan memberikan uraian lebih lanjut tentang pertemuan berikutnya.

7. Guru memberikan post tes pada siswa.

1. Kegiatan Awal

$$
\text { PERTEMUAN KETIGA }
$$

a. Guru mengecek jumlah kehadiran kepada siswa.

b. Guru menyampaikan pertanyaanpertanyaan tentang prinsip-prinsip kerja motor bensin dan motor diesel.

c. Apersepsi : Guru mengajukan pertanyaan penguatan kepada siswa tentang motor bensin dan motor diesel.

d. Guru menjelaskan tentang materi yang akan di bahas.

2. Kegiatan inti

a. Siswa dibagi dalam kelompok dan setiap peserta dalam kelompok mendapat nomor

b. Guru membagikan materi ke kelompokkelompok

c. Siswa menyimak materi ajar

d. Guru memberikan soal tugas dan masing-masing kelompok mengerjakannya

e. Kelompok mendiskusikan jawaban yang benar dan memastikan kesemua anggota kelompok dapat mengetahui jawabannya

f. Guru memanggil salah satu nomor peserta/siswa yang dipanggil melaporkan hasil kerja dalam kelompoknya. g. Siswa yang lain menanggapi / menyampaikan pertanyaan, kemudian guru memanggil nomor yang lain dst.

3. Kegiatan Akhir

- Siswa bersama guru membuat kesimpulan materi hari ini.

- Guru memberikan tugas kepada peserta didik

- Guru menyampaikan materi untuk pertemuan berikutnya.

PERTEMUAN KEEMPAT

1. Kegiatan Awal

a. Absensi

b. Memotivasi dan Apersepsi

- Guru menyampaikan jenis mesin dengan penggerak motor bensin dan motor diesel

- Siswa menyimak tujuan pembelajaran yang diberikan oleh guru untuk kegiatan pembelajaran hari ini.

2. Kegiatan inti

- Guru mengajukan pertanyaan kepada siswa spesifikasi motor diesel

- Guru menjelaskan spesifikasi motor diesel

3. Kegiatan Akhir

- $\square$ Guru bersama siswa membuat simpulan dari materi yang telah dibahas.

○ $\square$ Guru memberikan tugas kepada peserta didik

- $\square$ Menyampaikan rencana pembelajaran pada pertemuan berikutnya.

a. Observasi

Kegiatan yang dilakukan pada tahap ini adalah melakukan pengamatan kemampuan afektif dan psikomotorik siswa melalui lembar observasi selama proses pembelajaran berlangsung. Kemampuan afektif siswa yang diamati terdiri dari keaktifan mengikuti pelajaran, kerjasama, kejujuran, menghargai orang lain, dan tanggung jawab. Kemampuan psikomotorik siswa yang diamati terdiri dari menyiapkan alat dan bahan, mengetahui spesifikasi motor diesel dan mencatat materi yang telah disampaikan.

b. Refleksi

Semua data yang diperoleh dari pelaksanaan tindakan dan proses observasi dikumpulkan, dianalisis dan dievaluasi untuk mengetahui berhasil atau tidaknya tindakan yang dilakukan. 


\section{DAFTAR PUSTAKA}

Ahmadi, Abu. (1991). Psikologi Umum. Bandung: Mandar Maju.

Ali dan Lukman. (1996). Kamus Besar Bahasa Indonesia (edisi II). Jakarta: Balai Pustaka.

Baharudin. (2009). Psikologi Pendidikan Refleksi Teoritis Terhadap Fenomena. Yogyakarta: Ar-Ruzz Media.

Buchori. (1991). Psikologi Pendidikan. Jakarta. PT. Aksara Baru.

Dalyono, M. (2001). Psikologi Pendidikan. Jakarta: PT. Rineka Cipta.

Djaali, (2007). Psikologi Pendidikan. Jakarta: PT. Bumi Aksara.

Djamarah, (2008). Psikologi Belajar. Jakarta: PT. Rineka Cipta.

Moleong, L.J. 2001. Metodologi Penelitian Kualitatif. Bandung: Remaja Roslan karya Company.

Muhibbin Syah. (2002). Psikologi Pendidikan
Dalam Pendekatan Baru. Bandung: PT. Remaja Rosdakarya.

Ngalim Purwanto. (2003). Psikologi Pendidikan. Bandung: PT. Remaja Rosdakarya.

Notoatmodjo, Soekidjo (2003). Pengembangan Sumber Daya Manusia. Jakarta: PT. Asdi Mahasatya.

Omar Hamalik. (2002). Perencanaan Pengajaran Berdasarkan Pendekatan Sistem. Jakarta: PT. Bumi Aksara.

Sanaky, Hujair (2009). Media Pembelajaran. Yogyakarta: Safiria Insani Press.

Slameto. (1995). Belajar dan Faktor-faktor yang Mempengaruhinya. Jakarta: PT. Rineka Cipta.

Suryabrata, (2002). Psikologi Pendidikan. Jakarta: PT. Raja Grafindo Persada.

Winkel, S. J. (1983). Psikologi Pendidikan dan Evaluasi Belajar. Jakarta: PT. Gramedia. 